\title{
Photosynthetic Adaptive Strategies in Evergreen and Semi-Deciduous Species of Mediterranean Maquis During Winter
}

\author{
Carmen Arena ${ }^{1}$ and Luca Vitale ${ }^{2}$ \\ ${ }^{1}$ Department of Structural and Functional Biology, \\ University of Naples Federico II, \\ 2Istituto per I Sistemi Agricoli e Forestali del Mediterraneo, \\ (ISAFoM - CNR) \\ Italy
}

\section{Introduction}

Mediterranean-type ecosystems are characterised by a particular temperature and rainfall regime that limits plant growth in both summer and winter seasons (Mitrakos, 1980; Larcher, 2000). Mediterranean plant community is very heterogeneous and include many evergreen and semi-deciduous species that present a complex mixture of elements, some deriving from in situ evolution, others having colonized the area from adjacent regions in different periods in the past (Blondel \& Aronson 1999; Gratani \& Varone, 2004). The result of this evolution is that the Mediterranean maquis species are well adapted to environmental stress conditions and successfully overcome them (Sànchez-Blanco et al., 2002; Varone \& Gratani, 2007).

Structural and physiological adaptations consist in a mixture of characteristics that make these species very resistant to stresses. High leaf consistency, leaf tissue density, leaf thickness, and reduced leaf area are traits improving drought resistance by decreasing photochemical damages to the photosynthetic system (Abril \& Hanano 1998; Castro-Díez et al. 1998; Gratani \& Ghia 2002).

In this study we have focused our attention on photosynthetic adaptive strategies in Mediterranean evergreen and semi-deciduous species subjected to winter temperatures.

Winter depression of photosynthetic activity, occurring between December and February, is the consequence of low temperatures which are responsible for slowing down metabolic processes and cessation of growth (Rhizopoulou et al., 1989; Larcher, 2000).

Under these conditions, photosynthetic performance may decline and may be restored when the environmental conditions become favourable for growth in spring (Larcher, 2000; Oliveira \& Peñuelas, 2004). The combination of low temperatures and high light, may induce a reduction in photochemical efficiency, increasing the sensitivity of photosystems to photoinhibition (Powles, 1984). Mediterranean plant communities comprise many evergreen and semi-deciduous species that cope with winter cold through different strategies that include biochemical, physiological, anatomical and cytological modifications (Huner et al., 1981; Boese \& Huner 1990; Long et al., 1994; Oliveira \& Peñuelas, 2000; Tattini et al., 2000). 
The chilling-induced photosynthetic decline can be attributed both to a reduced activity of enzymes involved in the photosynthetic carbon reduction cycle (Sassenrath et al., 1990; Hutchinson et al., 2000), or to a photoinhibitory process. In fact, when chilling is protracted for a long time, the reduction of carbon assimilation can lead to an increase of excitation energy to reaction centres, that if not safely dissipated, induces damages at photosystems level compromising the whole photosynthetic apparatus (Baker, 1994; Tjus et al., 1998). However, in nature, the photosynthetic decrease as well as the reduction of photochemical activity at low temperatures, often represent a regulatory mechanism associated with photoprotective strategies that promote the dissipation of excess excitation energy avoiding irreversible damages to photosystems (Long et al., 1994; D'Ambrosio et al., 2006). Several mechanisms have evolved in plants in order to protect photosystems against photodamages; they include thermal dissipation, chloroplasts movements, chlorophyll concentration changes, increases in the capacity for scavenging the active oxygen species and the PSII ability to transfer electrons to acceptors different from $\mathrm{CO}_{2}$ (Niyogi, 2000).

It has been reported that the resistance of Mediterranean maquis evergreen species to photoinhibition is associated mainly to the increase in scavenging capacity and thermal dissipation processess, as well as to the increment of carotenoids pool or reduction in chlorophyll content (Garcìa-Plazaola et al., 1999, 2000; Arena et al., 2008). On the other hand, the semi-deciduous species such as Cistus rely on pheno-morphological features such as short lifetime of leaves and leaf pubescence to protect leaves from the excess of light and, thus, reduce the investment in other physiological mechanisms (Werner et al., 1999; Oliveira \& Peñuelas, 2001, 2002, 2004). Previous studies have demonstrated that the resistance to environmental constraints such as low temperature or high irradiance can depend on leaf age (Shirke, 2001; Bertamini \& Nedunchezhian, 2003). Young and mature leaves may differ both in photosynthetic performance and some leaf functional traits such as the sclerophylly index LMA (leaf mass per area) and its opposite leaf specific area (SLA), leaf dry matter content (LDMC) and relative water content (RWC). These properties affect significantly the whole plant physiology. More specifically, LMA variations are linked to biomass allocation strategies (Wilson et al., 1999) and to photosynthetic acclimation under different conditions, RWC is a good indicator to evaluate the plant water status (Cornelissen et al., 2003; Teulat et al., 1997) and LDMC represent an index of resource use by plant (Garnier et al., 2001). LDMC is related to leaf lifespan and it is involved in the trade-off between the quick production of biomass and the efficient conservation of nutrients (Poorter \& Garnier, 1999; Ryser \& Urbas, 2000). Generally young leaves appears more vulnerable than mature leaves to stress, since have a reduced degree of xeromorphism (lower LMA). In this chapter has been examined the photosynthetic and photochemical behaviour of young and mature leaves of different species of the Mediterranean maquis, grown during the winter, in response to low temperatures. In particular our attention has been focused on the evergreen species Laurus nobilis L., Phillyrea angustifolia L. and Quercus ilex L. and on the semi-deciduous species Cistus incanus L. that are widespread in Southern Italy area. Our specific purposes were: 1) to focus on eco-physiological strategies adopted by the different species to optimize the carbon gain during winter and minimize the photoinhibitory damage risks; 2) to compare the behaviour of young and mature leaves under low winter temperature in order to elucidate if the photoprotective mechanisms may be influenced by the leaf age. 


\section{Material and methods}

Two different experiments have been considered in this study; the first experiment has been carried out on evergreens L. nobilis, $P$. angustifolia and $Q$. ilex and analyzes the photosynthetic and the photochemical performance of young and mature leaves during the winter and of mature leaves during the winter and following spring. The second experiment is focused on the photochemical behaviour of young and mature leaves of the semideciduous species $C$. incanus during winter and of mature leaves during the winter and the following spring. It is well know that the $C$. incanus species produces two different typologies of leaves: winter leaves and summer leaves with dissimilar morpho-anatomical traits (Aronne \& De Micco, 2001). In the present study only winter leaves have been examined. The experimental planning of the work is reported in Fig. 1.

\subsection{The experimental planning schema}

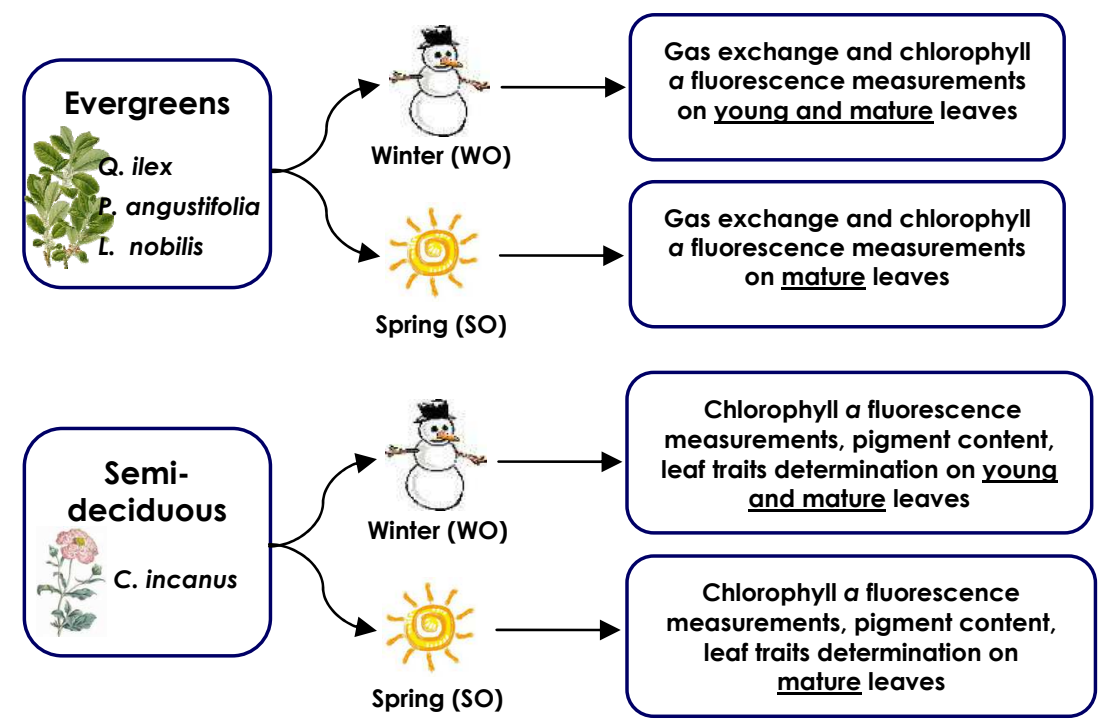

Fig. 1. The experimental planning of the work.

\subsection{Plant material and growth conditions}

First experiment. Two years old plants of $Q$. ilex, P. angustifolia and L. nobilis coming from the garden centre of Corpo Forestale dello Stato of Sabaudia (Latina, Italy) were transplanted in $15 \mathrm{~L}$ pots in January 2004 and placed outdoor in the Botanical Garden of Naples University for one year. Pots were large enough to avoid limitations in root growth and were filled with a mixture of peat and soil in the proportion 50:50. The temperature conditions at the experimental site during plant growth were typical of the Mediterranean region with cold winters and warm summers (Fig. 2A). Gas exchange and chlorophyll $a$ fluorescence measurements were performed in winter (early March 2005) and in spring (during May 2005); for winter measurements, 8 mature leaves of one year old and 8 young 
leaves sprouted in late October of the previous year, were selected randomly for each species from 4 different plants. The photosynthetic behaviour of one-year old leaves in winter was compared with that of one-year old leaves in spring.

Second experiment. In November 2007, eight plants of C. incanus, of three years old, were collected in the field in the Castel Volturno Natural reserve (Naples, Italy). The climate of the reserve is typically Mediterranean, with dry summers and rainy autumns and winters. The main vegetation type is maquis often opening into garrigue formations dominated by evergreen sclerophylls and seasonally dimorphic species.

The collected plants were excavated in situ and quickly transplanted in $15 \mathrm{~L}$ pots filled with native soil, then were carried to the Department of Structural and Functional Biology of Naples University and placed outdoors in a open area of the Department. The temperature conditions experienced by plants during growth are shown in Fig. 2B. Outdoor temperatures at the experimental site, during the experimental period, ranged between minimum values of $2{ }^{\circ} \mathrm{C}$ and maximum values of $16^{\circ} \mathrm{C}$.

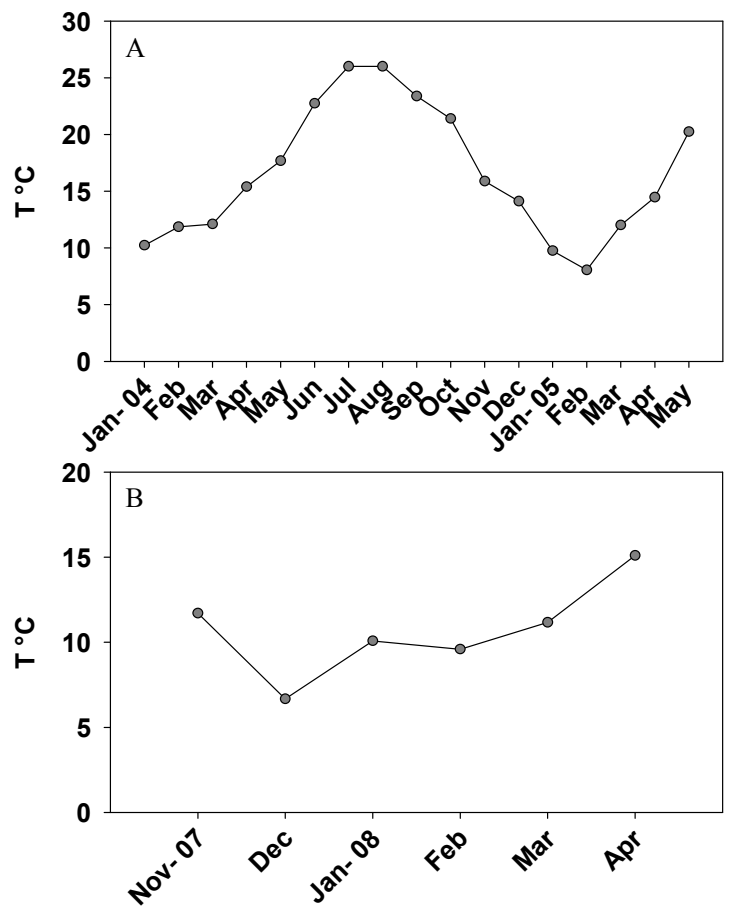

Fig. 2. Monthly mean air temperature $\left(\mathrm{T}^{\circ} \mathrm{C}\right)$ at the two experimental sites during the evergreens growth (A) and C. incanus growth (B). Data have been collected from Naples Largo San Marcellino weather station.

At the beginning of February, three healthy plants were selected for eco-physiological analyses; young leaves of about 15 days old and mature leaves of about 30 days old were 
chosen for photochemical measurements and photosynthetic pigments and leaf functional traits determinations. At the end of April, mature leaves were analysed again and compared to mature leaves in winter on basis of chlorophyll $a$ fluorescence measurements, chlorophyll content and leaf functional traits determinations. All analyses were carried out on six leaves from 3 different specimens.

\subsection{Gas exchange and chlorophyll a fluorescence measurements}

In the first experiment, on the three evergreen species, gas exchange and chlorophyll $a$ fluorescence measurements were performed simultaneously in winter (March 2008) and in spring (May 2005) by a portable gas exchange system (HCM-1000, Walz, Germany) in a climatized cuvette equipped with a fiber optic connected with a portable pulse amplitude modulated fluorometer (Mini-PAM, Walz, Germany). All measurements were performed at midday under clear-sky conditions. In winter both young and mature leaves were analysed, in spring only mature leaves were considered.

In the second experiment, on the semi-deciduous species C. incanus L. measurements of chlorophyll $a$ fluorescence were performed by a portable pulse amplitude modulated fluorometer (Mini-PAM, Walz, Germany) equipped with a leaf-clip holder (Leaf-Clip Holder 2030-B, Walz, Germany), which allows the simultaneous recording of the incident photosynthetic photon flux density on the leaf and abaxial leaf temperature. Measurements were performed at midday, under natural light and temperature conditions, on young and mature leaves, during winter (February 2008), and on mature leaves during spring (April 2008). The air temperature $\left(\mathrm{T}_{\text {air }}\right)$ and the Photosynthetic Photon Flux Densities (PPFD) experienced by $C$. incanus leaves at midday, during the days of measurements, are reported in Table 1.

\begin{tabular}{cccc}
$\mathbf{T}_{\text {air }}$ & $\begin{array}{c}\text { Days of } \\
\text { measurements }\end{array}$ & Young leaves & Mature leaves \\
\cline { 2 - 4 } & 2 Feb 2008 & $12 \pm 0.12$ & $11 \pm 0.22$ \\
PPFD & 29 Apr 2008 & - & $22 \pm 0.05$ \\
\cline { 2 - 4 } & 2 Feb 2008 & $693 \pm 28$ & $712 \pm 29$ \\
& 29 Apr 2008 & - & $1074 \pm 28$ \\
\hline
\end{tabular}

Table 1. Air temperature $\left(\mathrm{T}_{\text {air }},{ }^{\circ} \mathrm{C}\right)$ and Photosynthetic photon flux density (PPFD, $\mu \mathrm{mol}$ photons $\mathrm{m}^{-2} \mathrm{~s}^{-1}$ ) measured at midday on $C$. incanus plants at the experimental site in the days of measurements. Data reported are means $\pm \mathrm{SE}(\mathrm{n}=6)$.

For gas exchange measurements, each leaf has been kept in cuvette for 5-6 min. The acquisition of data was made when steady-state rate of net assimilation was achieved. A constant photosynthetic photon flux density (PPFD) of $1000 \mu \mathrm{mol}$ photons $\mathrm{m}^{-2} \mathrm{~s}^{-1}$ was provided to the leaves by an external light source (1050-H, Walz, Germany) positioned on the cuvette plane. The PPFD of $1000 \mu \mathrm{mol}$ photons $\mathrm{m}^{-2} \mathrm{~s}^{-1}$ was selected in order to obtain the values of light-saturated net photosynthetic rate for each species.

Net photosynthetic rate $\left(\mathrm{A}_{\mathrm{N}}\right)$, stomatal conductance to water $\left(\mathrm{g}_{\mathrm{H} 2 \mathrm{O}}\right)$ and intercellular $\mathrm{CO}_{2}$ concentration $\left(C_{\mathrm{i}}\right)$ were calculated by the software operating in HCM-1000 using the von 
Caemmerer and Farquhar equations (1981). The ratio of intercellular to ambient $\mathrm{CO}_{2}$ concentration, $\mathrm{C}_{\mathrm{i}} / \mathrm{C}_{\mathrm{a}}$, was used to calculate the apparent carboxylation efficiency.

As concerns chlorophyll $a$ fluorescence measurements, in the early morning, on $30 \mathrm{~min}$ dark-adapted leaves, the background fluorescence signal, $F_{o}$, was induced by light of about $0.5 \mu \mathrm{mol}$ photons $\mathrm{m}^{-2} \mathrm{~s}^{-1}$ at the frequency of $0.6 \mathrm{kHz}$. In order to determine the maximal fluorescence level in the dark-adapted state, $F_{m}$, a 1s saturating light pulse $(10000 \mu \mathrm{mol}$ photons $\mathrm{m}^{-2} \mathrm{~s}^{-1}$ ) was applied by previously setting the frequency at $20 \mathrm{kHz}$; the maximum PSII photochemical efficiency $\left(\mathrm{F}_{\mathrm{v}} / \mathrm{F}_{\mathrm{m}}\right)$ was calculated as:

$$
\left[\mathrm{F}_{\mathrm{v}} / \mathrm{F}_{\mathrm{m}}=\left(\mathrm{F}_{\mathrm{m}}-\mathrm{F}_{\mathrm{o}}\right) / \mathrm{F}_{\mathrm{m}}\right]
$$

The saturating pulse intensity was chosen in order to saturate the fluorescence yield but avoiding photoinhibition during the pulse.

At midday, the steady-state fluorescence signal $\left(\mathrm{F}_{\mathrm{t}}\right)$ and the maximal fluorescence $\left(\mathrm{F}_{\mathrm{m}}{ }^{\prime}\right)$ under illumination were measured, setting the light measure at a frequency of $20 \mathrm{kHz}$. $\mathrm{F}_{\mathrm{m}}{ }^{\prime}$ was determined by a $1 \mathrm{~s}$ saturating light pulse $\left(10000 \mu \mathrm{mol}\right.$ photons $\left.\mathrm{m}^{-2} \mathrm{~s}^{-1}\right)$. The partitioning of absorbed light energy was calculated following the model of Kramer et al. (2004). The quantum yield of PSII linear electron transport $\left(\Phi_{\mathrm{PSII}}\right)$ was estimated following Genty et al. (1989) as:

$$
\Phi_{\text {PSII }}=\left(F_{m}{ }^{\prime}-F_{t}\right) / F_{m}{ }^{\prime}
$$

The yields of regulated energy dissipation was calculated as:

$$
\Phi_{\mathrm{NPQ}}=1-\Phi_{\mathrm{PSII}}-1 /\left(\mathrm{NPQ}+1+\mathrm{q}_{\mathrm{L}} \times\left(\mathrm{F}_{\mathrm{m}} / \mathrm{F}_{\mathrm{o}}-1\right)\right.
$$

whereas the non-regulated energy dissipation in PSII was calculated as:

$$
\Phi_{\mathrm{NO}}=1 /\left(\mathrm{NPQ}+1+\mathrm{q}_{\mathrm{L}} \times\left(\mathrm{F}_{\mathrm{m}} / \mathrm{F}_{\mathrm{o}}-1\right)\right)
$$

The coefficient of photochemical quenching, qL, was defined and calculated following Kramer et al. (2004) as:

$$
\left(\mathrm{F}_{\mathrm{m}}{ }^{\prime}-\mathrm{F}_{\mathrm{t}}\right) /\left(\mathrm{F}_{\mathrm{m}}{ }^{\prime}-\mathrm{F}_{\mathrm{o}}{ }^{\prime}\right) \times \mathrm{F}_{\mathrm{o}}{ }^{\prime} / \mathrm{F}_{\mathrm{t}}=\mathrm{q}_{\mathrm{p}} \times \mathrm{F}_{\mathrm{o}}{ }^{\prime} / \mathrm{F}_{\mathrm{t}}
$$

The value of $\mathrm{F}_{\mathrm{o}}{ }^{\prime}$ was estimated as: $\mathrm{F}_{\mathrm{o}}{ }^{\prime}=\mathrm{F}_{\mathrm{o}} /\left(\mathrm{F}_{\mathrm{v}} / \mathrm{F}_{\mathrm{m}}+\mathrm{F}_{\mathrm{o}} / \mathrm{F}_{\mathrm{m}}{ }^{\prime}\right)$ (Oxborough \& Baker, 1997). Non-photochemical quenching was expressed according to Bilger \& Björkman (1990) as:

$$
\left[\mathrm{NPQ}=\left(\mathrm{F}_{\mathrm{m}}-\mathrm{F}_{\mathrm{m}}{ }^{\prime}\right) / \mathrm{F}_{\mathrm{m}}{ }^{\prime}\right]
$$

The statistical analysis of the data was performed by one-way ANOVA followed by Student-Newman-Keuls test (Sigma-Stat 3.1) based on a significance level of $\mathrm{P}<0.05$. Data are means \pm SE (at least $n=6$ ).

\subsection{Photosynthetic pigment content and functional leaf traits determination}

After fluorescence measurements, leaves were detached from C. incanus plants and carried to the laboratory for the photosynthetic pigment content determination. Pigments were extracted with a mortar and pestle in ice-cold 100\% acetone and quantified by a spectrophotometer according to Lichtenthaler (1987). A different group of leaves of comparable age to those used for fluorescence measurements and pigment determinations, was collected and utilized for the specific leaf area (SLA) and leaf dry matter content 
(LDMC) measurements. Specific leaf area was calculed as the ratio of leaf area to leaf dry mass and expressed as $\mathrm{cm}^{2} \mathrm{~g}^{-1} \mathrm{dw}$ (dry weight). For dry mass determination, leaves were dried at $70{ }^{\circ} \mathrm{C}$ for $48 \mathrm{~h}$. Leaf dry matter content (LDMC) was measured as the oven-dry mass of a leaf divided by its water-saturated fresh mass and expressed as $\mathrm{g} \mathrm{g}^{-1}$ wslm (water saturated leaf mass). Leaf dry matter content is related to the average density of the leaf tissues (Cornelissen et al., 2003).

\section{Results}

\subsection{Young and mature leaves of $L$. nobilis L., $P$. angustifolia $L$. and Quercus ilex $L$. during winter}

During winter, mature leaves of all species showed an higher $(\mathrm{P}<0.001)$ net photosynthetic rate $\left(\mathrm{A}_{\mathrm{N}}\right)$ compared to young leaves. In both young and mature leaves the highest $(\mathrm{P}<0.001)$ $\mathrm{A}_{N}$ values were measured in $Q$. ilex whereas the lowest $(\mathrm{P}<0.001)$ in L. nobilis (Fig. 3A, D).

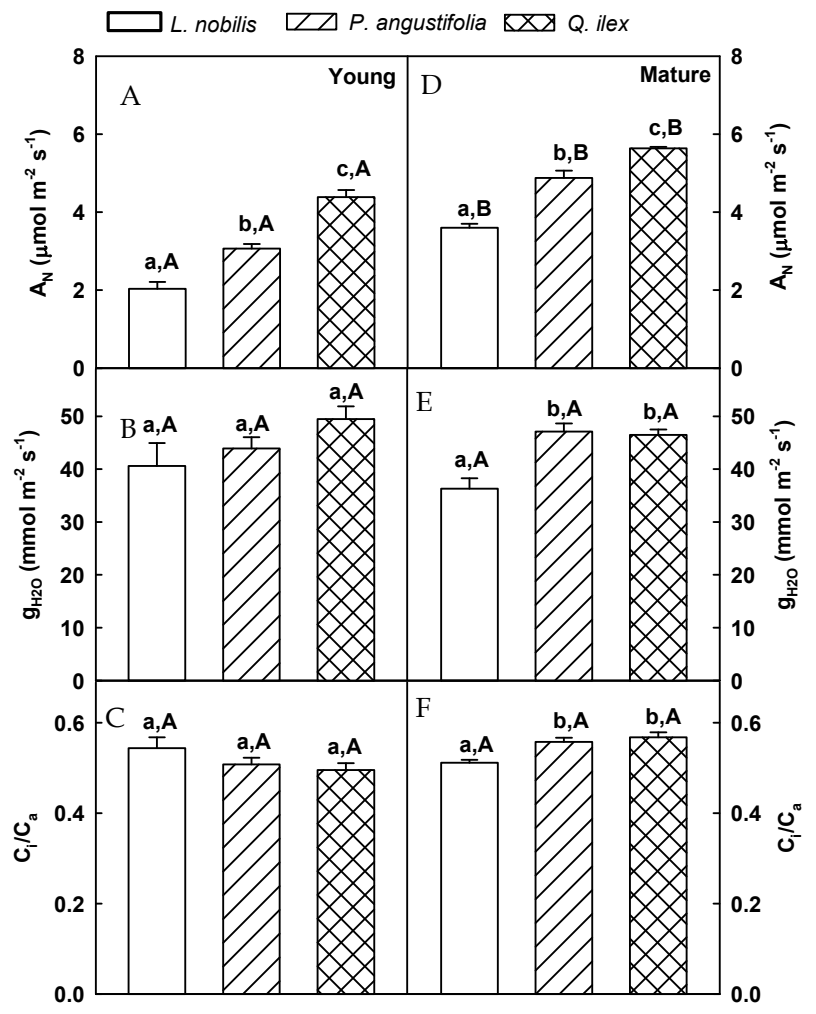

Fig. 3. Net photosynthetic rate $\left(\mathrm{A}_{\mathrm{N}}\right)$, stomatal conductance to water $\left(\mathrm{g}_{\mathrm{H} 2 \mathrm{O}}\right)$ and ratio of intercellular to ambient $\mathrm{CO}_{2}$ concentration $\left(\mathrm{C}_{\mathrm{i}} / \mathrm{C}_{\mathrm{a}}\right)$ in young and mature leaves of Laurus nobilis, Phillyrea angustifolia and Quercus ilex, during winter. Different letters indicate statistical differences between young and mature leaves (small letters) and among species (capital letters). Values are means \pm SD $(n=8)$. 


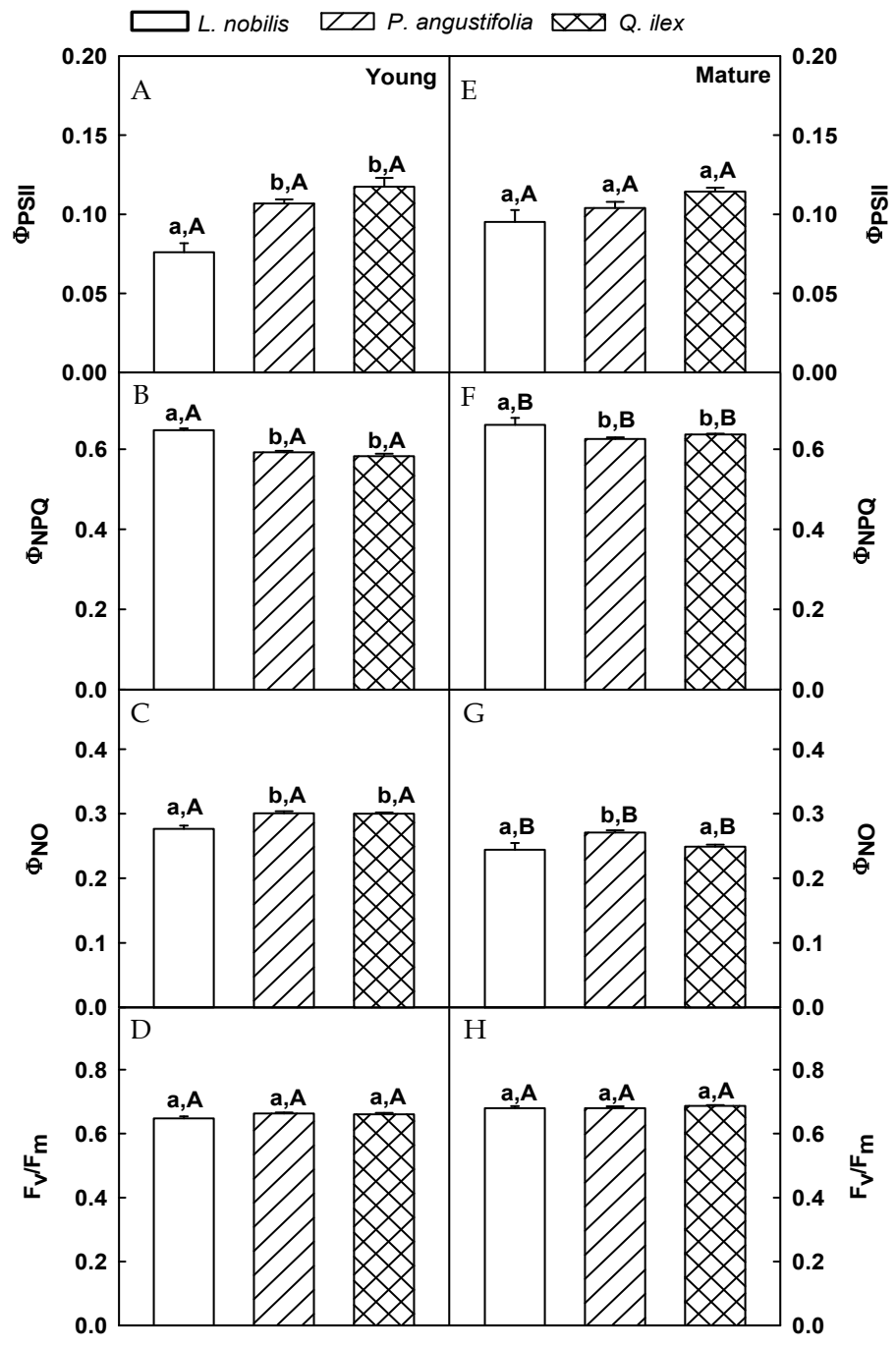

Fig. 4. Quantum yield of linear PSII electron transport ( $\left.\Phi_{\mathrm{PSI}}\right)$, regulated energy dissipation $\left(\Phi_{\mathrm{NPQ}}\right)$, non-regulated energy dissipation $\left(\Phi_{\mathrm{NO}}\right)$ and maximum PSII photochemical efficiency $\left(\mathrm{F}_{\mathrm{v}} / \mathrm{F}_{\mathrm{m}}\right)$ in young and mature leaves of Laurus nobilis, Phillyrea angustifolia and Quercus ilex, during winter. Different letters indicate statistical differences between young and mature leaves (small letters) and among species (capital letters). Values are means $\pm S D(n=8)$.

In young leaves, stomatal conductance to water $\left(\mathrm{g}_{\mathrm{H} 2 \mathrm{O}}\right)$ did not differ among the species; on the contrary, in mature leaves $\mathrm{g}_{\mathrm{H} 2 \mathrm{O}}$ was significantly lower $(\mathrm{P}<0.01)$ in L. nobilis than $P$. angustifolia and $Q$. ilex. No significant difference in $\mathrm{g}_{\mathrm{H} 2 \mathrm{O}}$ between young and mature leaves of the same species was measured (Fig. 3B, E). 
The ratio of intercellular to ambient $\mathrm{CO}_{2}$ concentration $\left(\mathrm{C}_{\mathrm{i}} / \mathrm{C}_{\mathrm{a}}\right)$ was similar for young leaves of all species, conversely in mature leaves was lower $(\mathrm{P}<0.001)$ in $L$. nobilis compared to $P$. angustifolia and $Q$. ilex. No significant difference within young and mature leaves of the same species was observed in $\mathrm{C}_{\mathrm{i}} / \mathrm{C}_{\mathrm{a}}$ ratio (Fig. $3 \mathrm{C}, \mathrm{F}$ ).

The analysis of photochemistry showed that, among young leaves of different species, the quantum yield of PSII linear electron transport $\left(\Phi_{\mathrm{PSII}}\right)$ was higher $(\mathrm{P}<0.005)$ in P. angustifolia and $Q$. ilex compared to L. nobilis (Fig. 4A) on the contrary L. nobilis showed the highest regulated energy dissipation, $\Phi_{\mathrm{NPQ}},(\mathrm{P}<0.05)$ and the lowest $(\mathrm{P}<0.005)$ non-regulated energy dissipation, $\Phi_{\mathrm{NO}}$, compared to other species. No difference was detected in $\Phi_{\mathrm{NPQ}}$ and $\Phi_{\mathrm{NO}}$ between $P$. angustifolia and $Q$. ilex (Fig. 4B, C). All mature leaves exhibited no significant difference in $\Phi_{\mathrm{PSII}}$ (Fig. 4E) but leaves of L. nobilis showed again the highest $\Phi_{\mathrm{NPQ}}(\mathrm{P}<0.05)$; the highest $(\mathrm{P}<0.005) \Phi_{\mathrm{NO}}$ was found in $P$. angustifolia (Fig. $\left.4 \mathrm{~F}, \mathrm{G}\right)$. No variation in maximum PSII photochemical efficiency $\left(\mathrm{F}_{\mathrm{v}} / \mathrm{F}_{\mathrm{m}}\right)$ among different species and between young and mature leaves were found (Fig. $4 \mathrm{D}, \mathrm{H}$ ). The comparison between young and mature leaves evidenced no difference in $\Phi_{\mathrm{PSII}}$ and lower $(\mathrm{P}<0.001)$ and higher $(\mathrm{P}<0.005)$ values of $\Phi_{\mathrm{NPQ}}$ and $\Phi_{\mathrm{NO}}$, respectively, in mature leaves.

\subsection{Mature leaves of $L$. nobilis L., $P$. angustifolia L. and Quercus ilex L. during winter and spring}

During winter, within different species, $Q$. ilex showed higher net photosynthetic rate $\left(\mathrm{A}_{\mathrm{N}}\right)$ $(\mathrm{P}<0.001)$ and stomatal conductance to water $\left(\mathrm{g}_{\mathrm{H} 2 \mathrm{O}}\right)(\mathrm{P}<0.05)$ as well as a lower $(\mathrm{P}<0.005)$ intercellular to ambient $\mathrm{CO}_{2}$ concentration ratio $\left(\mathrm{C}_{\mathrm{i}} / \mathrm{C}_{\mathrm{a}}\right)$ compared to $L$. nobilis and $P$. angustifolia (Fig. 5A, B, C). The lowest values of $\mathrm{A}_{\mathrm{N}}$ and $\mathrm{g}_{\mathrm{H} 2 \mathrm{O}}$ was found in L. nobilis. No significant difference between L. nobilis and P. angustifolia in $C_{i} / C_{a}$ ratio was found. During spring, among species, $Q$. ilex exhibited again the highest $(\mathrm{P}<0.001)$ net photosynthetic rate $\left(\mathrm{A}_{\mathrm{N}}\right)$ and the lowest $\mathrm{C}_{\mathrm{i}} / \mathrm{C}_{\mathrm{a}}$ ratio $(\mathrm{P}<0.05)$ compared to L. nobilis and P. angustifolia (Fig. $5 \mathrm{D}$, F), but similar values of $\mathrm{g}_{\mathrm{H} 2 \mathrm{O}}$ (Fig. $5 \mathrm{E}$ ).

The comparison between winter and spring showed that, during spring, an increase in $A_{N}$ $(\mathrm{P}<0.001)$ and $\mathrm{g}_{\mathrm{H} 2 \mathrm{O}}(\mathrm{P}<0.05)$ were observed in all species compared to winter (Fig. 5D, E); on the other hand, no significant difference in $\mathrm{C}_{\mathrm{i}} / \mathrm{C}_{\mathrm{a}}$ ratio was found (Fig. $5 \mathrm{~F}$ ).

During winter the photochemical performance varied among species (Fig. 6).

In particular, L. nobilis showed the lowest $(\mathrm{P}<0.001)$ quantum yield of PSII linear electron transport $\left(\mathrm{F}_{\mathrm{PSI}}\right)$ and non-regulated energy dissipation $\left(\Phi_{\mathrm{NO}}\right)$, as well as the highest $(\mathrm{P}<0.01)$ regulated energy dissipation $\left(\Phi_{\mathrm{NPQ}}\right)$ (Fig. $\left.6 \mathrm{~A}, \mathrm{~B}, \mathrm{C}\right)$. No difference in $\mathrm{F}_{\mathrm{v}} / \mathrm{F}_{\mathrm{m}}$ values was observed among species (Fig. 6 D).

During spring, $Q$. ilex and P. angustifolia showed an higher $(\mathrm{P}<0.001) \Phi_{\mathrm{PSII}}$ than L. nobilis (Fig. $6 \mathrm{E})$. The lowest $(\mathrm{P}<0.01) \Phi_{\mathrm{NPQ}}$ was detected in $Q$. ilex, whereas the highest $(\mathrm{P}<0.01) \mathrm{F}_{\mathrm{NO}}$ was found in L. nobilis (Fig. 6F, G). Similar values of maximum PSII photochemical efficiency, $\mathrm{F}_{\mathrm{v}} / \mathrm{F}_{\mathrm{m}}$, were observed among species (Fig. $6 \mathrm{H}$ ).

The comparison between the two campaign of measurements has evidenced that in all species $F_{\mathrm{PSII}}$ and $\Phi_{\mathrm{NPQ}}$ were respectively higher and lower $(\mathrm{P}<0.001)$ in spring than in winter (Fig. 6A, E, B, F). In spring compared to winter, $\Phi_{\mathrm{NO}}$ increased $(\mathrm{P}<0.01)$ only in L. nobilis, whereas decreased $(\mathrm{P}<0.05)$ in $P$. angustifolia and remained unvaried in $Q$. ilex (Fig. 6C, G). The maximum PSII photochemical efficiency $F_{v} / F_{m}$ was lower in winter as compared to spring $(\mathrm{P}<0.005)$ for all species $($ Fig. $6 \mathrm{D}, \mathrm{H})$. 


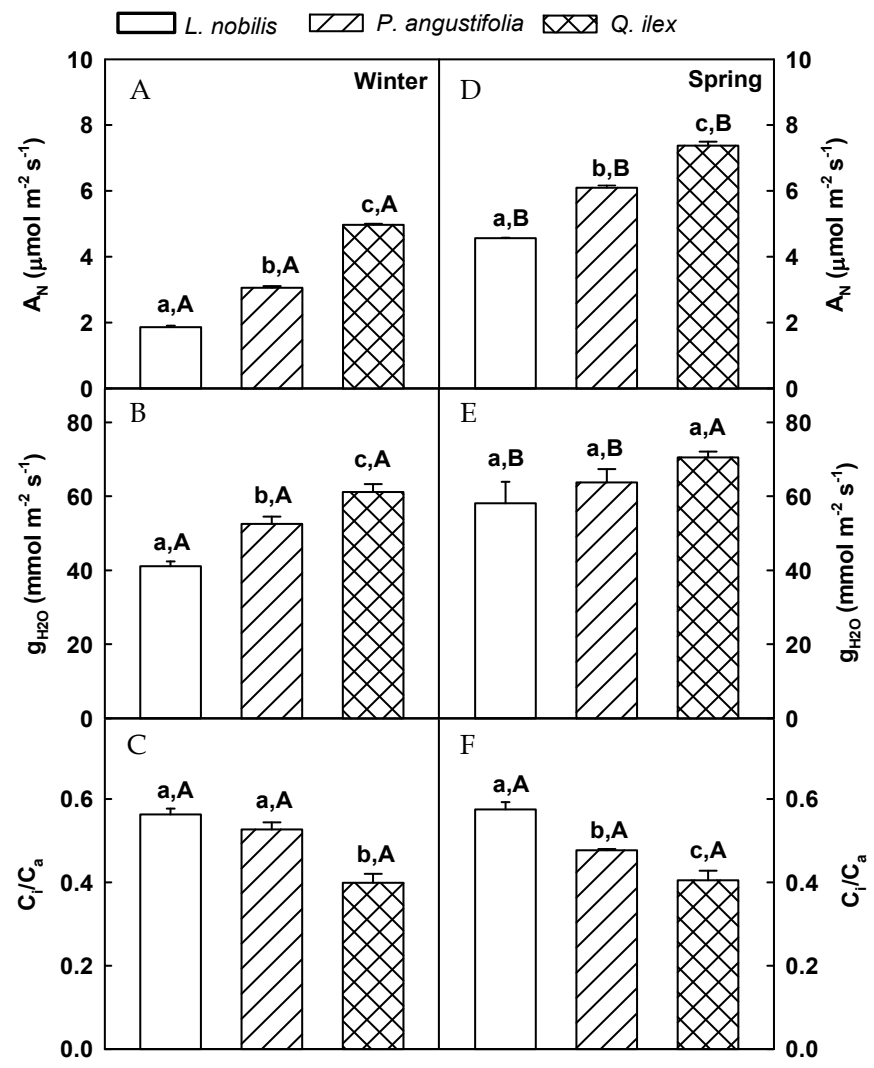

Fig. 5. Net photosynthetic rate $\left(\mathrm{A}_{\mathrm{N}}\right)$, stomatal conductance to water $\left(\mathrm{g}_{\mathrm{H} 2 \mathrm{O}}\right)$ and ratio of intercellular to ambient $\mathrm{CO}_{2}$ concentration $\left(\mathrm{C}_{\mathrm{i}} / \mathrm{C}_{\mathrm{a}}\right)$ in mature leaves of Laurus nobilis, Phillyrea angustifolia and Quercus ilex, during winter and spring. Different letters indicate statistical differences among species (small letters) and between seasons (capital letters). Values are means $\pm \mathrm{SD}(\mathrm{n}=8)$.

\subsection{The semi-deciduous species Cistus incanus L.}

The comparison between young and mature leaves of the semi-deciduous species $C$. incanus evidenced that the quantum yield of PSII linear electron transport ( $\Phi_{\text {PSII }}$ ) was lower in mature as compared to young leaves $(\mathrm{P}<0.001)$ whereas the quantum yield of regulated energy dissipation $\left(\Phi_{\mathrm{NPQ}}\right)$ showed an opposite tendency $(\mathrm{P}<0.05)$ (Fig. 7A, B). No significant difference in non regulated energy dissipation $\left(\Phi_{\mathrm{NO}}\right)$ and maximum photochemical efficiency $\left(\mathrm{F}_{\mathrm{v}} / \mathrm{F}_{\mathrm{m}}\right)$ was detected $(\mathrm{P}<0.05)$ between the two leaf typologies (Fig. 7C, D).

The photochemical behavior of mature $C$. incanus leaves was different during winter and the following spring. More specifically, in spring leaves showed higher values of $\Phi_{\mathrm{PSII}}(\mathrm{P}<0.001)$ and lower values of $\Phi_{\mathrm{NPQ}}$ and $\Phi_{\mathrm{NO}}(\mathrm{P}<0.005)$ compared to winter (Fig. 7E, F, G), whereas no significant difference in $F_{v} / F_{m}$ between the two seasons was observed (Fig. $7 \mathrm{H}$ ). 


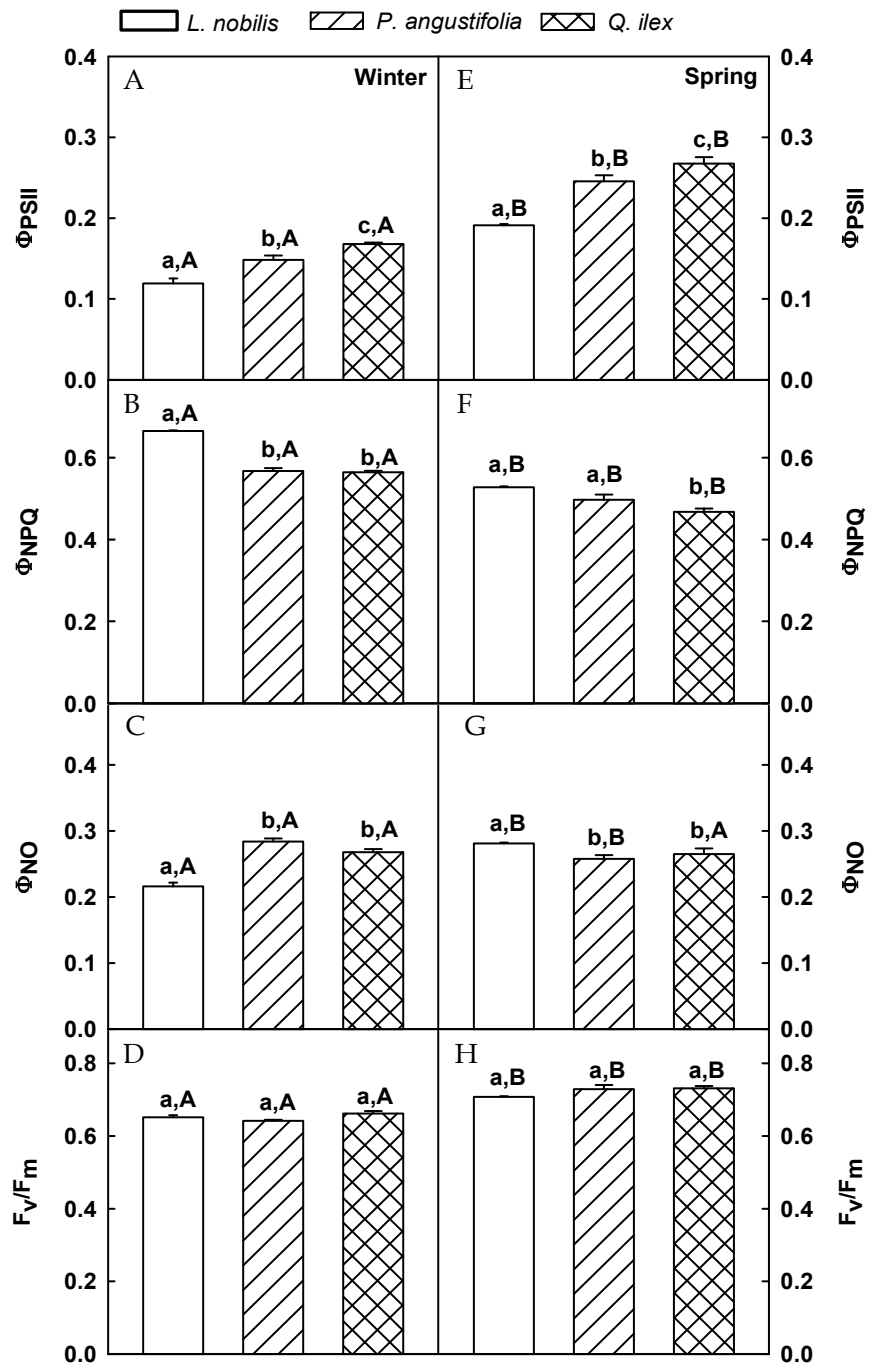

Fig. 6. Quantum yield of linear PSII electron transport $\left(\Phi_{\mathrm{PSII}}\right)$, regulated energy dissipation $\left(\Phi_{\mathrm{NPQ}}\right)$, non-regulated energy dissipation $\left(\Phi_{\mathrm{NO}}\right)$ and maximum PSII photochemical efficiency $\left(\mathrm{F}_{\mathrm{v}} / \mathrm{F}_{\mathrm{m}}\right)$ in mature leaves of Laurus nobilis, Phillyrea angustifolia and Quercus ilex, during winter and spring. Different letters indicate statistical differences among species (small letters) and between seasons (capital letters). Values are means $\pm S D(n=8)$.

The results relative to leaf functional traits and photosynthetic pigment content are reported in the table 2. The analysis of functional leaf traits has evidenced that, as compared to mature leaves, young leaves showed lower values $(\mathrm{P}<0.05)$ of leaf area $(\mathrm{LA})$, but no difference in specific leaf area (SLA) and leaf dry matter content (LDMC). Functional leaf 
traits did not show any difference between mature leaves in both winter and spring campaigns. The total chlorophyll content, chl $(\mathrm{a}+\mathrm{b})$, as well as the total carotenoid content, car $(x+c)$, were higher in mature than in $(P<0.01)$ young leaves, that showed a lower $(P<0.05)$ $\mathrm{chl} \mathrm{a/b}$ ratio. No difference in total chlorophyll and carotenoid content, between winter and spring, in mature leaves was detected.

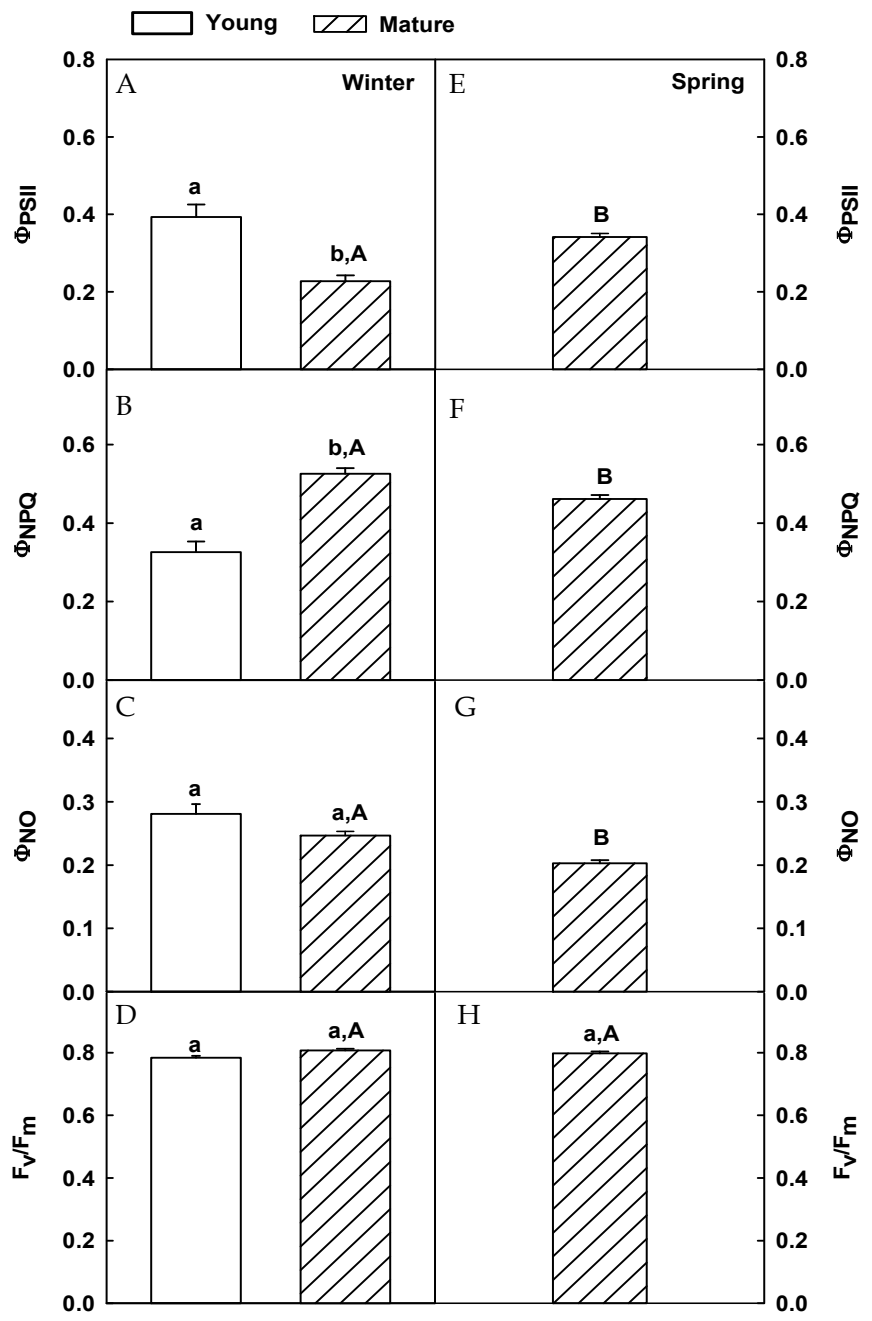

Fig. 7. Quantum yield of linear PSII electron transport $\left(\Phi_{\mathrm{PSII}}\right)$, regulated energy dissipation $\left(\Phi_{\mathrm{NPQ}}\right)$, non-regulated energy dissipation $\left(\Phi_{\mathrm{NO}}\right)$ and maximum PSII photochemical efficiency $\left(\mathrm{F}_{\mathrm{v}} / \mathrm{F}_{\mathrm{m}}\right)$ in C. incanus young and mature leaves during winter and in mature leaves during spring. Different letters indicate statistical differences between young and mature leaves (small letters) and between seasons (capital letters). Values are means $\pm \operatorname{SD}(n=6)$. 


\begin{tabular}{lcccc} 
& \multicolumn{2}{c}{ Winter } & Spring \\
\cline { 2 - 3 } \cline { 2 - 2 } & Young leaves & Mature leaves & & Mature leaves \\
\hline LA $\left(\mathrm{cm}^{2}\right)$ & $3.02 \pm 0.14 \mathrm{a}$ & $8.01 \pm 0.28 \mathrm{~b}$ & $8.32 \pm 0.44 \mathrm{~b}$ \\
SLA $\left(\mathrm{cm}^{2} \mathrm{~g}^{-1} \mathrm{dw}\right)$ & $127.13 \pm 11.68 \mathrm{a}$ & $120.40 \pm 4.96 \mathrm{a}$ & $134.03 \pm 8.88 \mathrm{a}$ \\
LDMC $\left(\mathrm{g} \mathrm{g}^{-1} \mathrm{wslm}\right)$ & $0.22 \pm 0.01 \mathrm{a}$ & $0.20 \pm 0.02 \mathrm{a}$ & $0.21 \pm 0.01 \mathrm{a}$ \\
chl $(\mathrm{a}+\mathrm{b})\left(\mu \mathrm{g} \mathrm{cm}^{-2}\right)$ & $57.90 \pm 1.18 \mathrm{a}$ & $76.61 \pm 5.8 \mathrm{~b}$ & $88,01 \pm 6 \mathrm{~b}$ \\
car $(\mathrm{x}+\mathrm{c})\left(\mu \mathrm{g} \mathrm{cm}^{-2}\right)$ & $11.09 \pm 0.29 \mathrm{a}$ & $14.22 \pm 1.05 \mathrm{~b}$ & $16 \pm 2.32 \mathrm{~b}$ \\
Chl a/b & $3.03 \pm 0.01 \mathrm{a}$ & $2.37 \pm 0.23 \mathrm{~b}$ & $2.5 \pm 0.34 \mathrm{~b}$ \\
\hline
\end{tabular}

Table 2. Leaf Area (LA), Specific Leaf Area (SLA), Leaf Dry Matter Content (LDMC), total chlorophyll $(\mathrm{chl} \mathrm{a}+\mathrm{b})$, total carotenoids $(\mathrm{car} \mathrm{x}+\mathrm{c})$ and chlorophyll $\mathrm{a} / \mathrm{b}$ ratio in $\mathrm{C}$. incanus young and mature leaves during winter and in mature leaves during spring. Data reported are means $\pm S E(n=6)$. Different letters indicate statistically significant differences.

\section{Discussion}

\subsection{Young and mature leaves of Laurus nobilis L., Phillyrea angustifolia L. and Quercus ilex L. in winter}

In disagreement with data reported in literature for other species (Urban et al., 2008), young leaves of all species showed lower $A_{N}$ values compared to mature ones, indicating a marked sensitivity to winter temperatures. It is likely to hypothesize that this could be attributable to a reduced capacity of the mesophyll to assimilate $\mathrm{CO}_{2}$ because no difference in apparent carboxilation efficiency $\left(\mathrm{C}_{\mathrm{i}} / \mathrm{C}_{\mathrm{a}}\right)$ between young and mature leaves was found. The significant differences between the two leaf populations, indicate the higher resistance of mature leaves photosynthetic machinery to low temperature. However, despite photosynthesis reduction, no variation in $\Phi_{\mathrm{PSII}}$ between young and mature leaves was detected; thus the lower $A_{N}$ values in young leaves may be due either to limitations in photosynthetic dark reactions or to additional dissipative processes, other than $\mathrm{CO}_{2}$ assimilation, active in consuming the reductive power of the electron transport chain (e.g. photorespiration and/or Mehler reaction). The fluorescence analysis has evidenced that in young leaves the excess of absorbed light was dissipated more by photochemical processes than by thermal dissipation associated to xanthophylls cycle, as indicated by lower $\Phi_{\mathrm{NPQ}}$ values compared to mature leaves. Although such photochemical processes are useful to protect the photosynthetic apparatus by photoinhibitory damage risks, it is well known that they can lead to an overproduction of reactive oxygen species (ROS). Even if ROS are continuously produced and removed during normal physiological events, when plants experience severe stress conditions, more $\mathrm{O}_{2}$ molecules are expected to be used as alternative electron acceptors disturbing the ROS production-removal balance and promoting the accumulation of ROS (Osório et al., 2011). Our results indicate that, in young leaves, under winter temperature, a large part of absorbed energy was diverted to nonregulated energy conversion processes (increase in $\Phi_{\mathrm{NO}}$ ) than in mature leaves, a circumstance that favors the production of ROS.

On the contrary, in mature leaves, more absorbed light was dissipated by thermal dissipation processes associated to xanthophylls cycle (higher $\Phi_{\mathrm{NPQ}}$ ). This result is in contrast with data reported by other authors who found a reduction in thermal dissipation by xanthophylls cycle as the leaves expanded (Choinski \& Eamus, 2003; Jiang et al., 2005). Our data suggest that leaf age influences the photoprotection mechanisms. More 
specifically, young and mature leaves regulate in a different way the dissipation of absorbed light energy in order to maintain high the photochemical efficiency. The absence of significant differences in $\mathrm{F}_{\mathrm{v}} / \mathrm{F}_{\mathrm{m}}$ ratio between the two leaf population indicates that both thermal dissipation and the alternative electron sink and/or additional quenching mechanism(s) are suitable for photoprotection, assuming a similar weight in photoprotection.

Among species, the higher $\mathrm{A}_{\mathrm{N}}$ rates in Q. ilex compared to P. angustifolia and L. nobilis in both young and mature leaves indicates $Q$. ilex as the species with more efficient photosynthetic process at low temperature (Ogaya \& Peñuelas, 2003). This is likely due to the highest utilization of reductive power of electron transport chain in $C$ fixation rather than in dissipative processes under low temperature. Our data demonstrate that under low temperatures, the strategies utilized to dissipate the excess of absorbed light vary among species. In particular in both young and mature leaves, L. nobilis, as compared to $P$. angustifolia and $Q$. ilex, diverts more excitation energy to regulated energy dissipation processes than to non-regulated energy dissipation processes (higher $\Phi_{\mathrm{NPQ}}$, lower $\Phi_{\mathrm{NO}}$ ). These different mechanisms seem equally important in maintaining an elevated maximum PSII photochemical efficiency, as confirmed by comparable $\mathrm{F}_{\mathrm{v}} / \mathrm{F}_{\mathrm{m}}$ ratio in all species.

\subsection{Mature leaves of L. nobilis L., P. angustifolia L. and Quercus ilex L. during winter and spring}

Equinoctial periods, characterized by the absence of drought and cold stress, are the most favorable seasons for the photosynthetic activity of Mediterranean vegetation (Savè et al., 1999). Data presented in this section are consistent with literature, indeed in spring, compared to winter, high rates of gas exchanges and a better photochemical efficiency were measured for all species. The highest values of $A_{N}$ and $g_{\mathrm{H} 2 \mathrm{O}}$ measured during winter in $Q$. ilex, suggest for this species a better resistance to low temperature (Ogaya \& Peñuelas, 2003), differently from $L$. nobilis that showed the lowest photosynthetic activity and stomatal conductance and the highest $C_{i} / C_{a}$ ratio. This latter constitutes a proxy tool to evaluate the occurrence of non-stomatal limitations to photosynthesis. In L. nobilis, the similar $C_{i} / C_{a}$ values found in winter compared to spring, despite the low photosynthetic activity, denote the presence of non-stomatal limitation to photosynthetic process likely due to a reduced activity of Rubisco (Sage \& Sharkey, 1987), and/or of other carbon assimilation enzymes (Sassenrath et al., 1990) at low temperatures. The analysis of photosynthetic energy partitioning evidenced that in winter, when net $\mathrm{CO}_{2}$ assimilation was limited by low temperatures, more absorbed energy was converted into regulated energy dissipation (higher $\Phi_{\mathrm{NPQ}}$ ) compared to spring. On the contrary, in spring when air temperature became favourable for photosynthesis, the absorbed energy was diverted mainly to net $\mathrm{CO}_{2}$ assimilation (higher $\left.\Phi_{\mathrm{PSII}}\right)$ and only a little in non-regulated energy dissipation (low $\Phi_{\mathrm{NO}}$ ). The higher thermal dissipation and the low $F_{v} / F_{m}$ values in winter compared to spring were likely the result of a photoprotective mechanisms by which plants cope with winter stress. This strategy is probably based on maintaining PSII primed for energy dissipation and engaged in diurnal energy dissipation throughout the night (Adams et al., 2001).

\subsection{Cistus incanus L. young and mature leaves in winter}

Under winter temperature, C. incanus young leaves exhibit a higher photochemical activity than mature leaves. The utilization of reductive power of electron transport in 
photochemistry reduces the need for the thermal dissipative process, in particular the fraction of the regulated thermal energy dissipation (low $\Phi_{\mathrm{NPQ}}$ values). Mature leaves showed an opposite tendency. However in both leaf typologies no variation of nonregulated energy dissipation component $\left(\Phi_{\mathrm{NO}}\right)$ was found. High values of $\Phi_{\mathrm{NPQ}}$ are indicative of a high photoprotective capacity, whereas high values of $\Phi_{\mathrm{NO}}$ may reflect the inability of a plant to protect itself against photodamage (Klughammer \& Schreiber, 2008; Osório et al., 2011). In our opinion, as maximum PSII photochemical efficiency $\left(F_{v} / F_{m}\right)$ and $\Phi_{\mathrm{NO}}$ are similar in the two leaf populations, we suppose that the different strategies adopted by young and mature leaves are equally helpful in leaf photoprotection under winter temperatures.

The acclimation of plants in relation to the environmental conditions is expressed, among other factors, also by their leaf characteristics (Bussotti et al., 2008) and photosynthetic pigment adjustments.

Functional leaf traits analyses indicate that, even if specific leaf area (SLA) as well as the leaf dry matter content (LDMC) do not vary between young and mature C. incanus leaves, mature leaves present a greater leaf blade and have a higher total chlorophyll and carotenoid contents per unit leaf area. The adjustment of photosynthetic pigment composition in mature leaves could be interpreted as further strategy in order to enhance the light harvest and thus compensate for the reduction in allocation of absorbed light in photochemistry.

\subsection{Cistus incanus L. mature leaves in winter and spring}

The behaviour of $C$. incanus mature leaves differ in winter and spring. The analysis of photochemistry showed that temperatures of $11{ }^{\circ} \mathrm{C}$ does not injure the photosynthetic apparatus, but affects significantly its efficiency. Indeed, the low values of $\Phi_{\text {PSII }}$ evidenced a decline in photochemical activity that may lead to an increase of excitation pressure in photosystem II with important consequence for the plant cells in terms of decrease of intracellular ATP and NADP production. On the other hand, the fraction of the regulated energy dissipation $\left(\Phi_{\mathrm{NPQ}}\right)$ higher in leaves during winter compared to spring, indicates that the regulated thermal dissipation for winter leaves was enhanced under low temperature to compensate for reduced photochemistry. Nevertheless during winter, leaves show also an higher non-regulated energy dissipation in PSII $\left(\Phi_{\mathrm{NO}}\right)$, indicating the occurrence of a stress condition for photosynthetic apparatus (Osòrio et al., 2011). It is reasonable to hypothesize that leaves during winter cope with low temperature by means of flexible component of thermal energy dissipation and the alternative electron sink and/or additional quenching mechanism(s). These factors may contribute to the high stress resistance of $C$. incanus leaves and allow photosynthetic apparatus to maintain during winter a high maximal PSII photochemical efficiency $\left(\mathrm{F}_{\mathrm{v}} / \mathrm{F}_{\mathrm{m}}\right)$.

The $F_{v} / F_{m}$ values found in leaves during winter were close to those reported for winter leaves of other Cistus species as well as to those of unstressed plants of other Mediterranean species (Oliveira \& Peñuelas, 2001, 2004). In spring, after the return to mild temperatures (i.e. $\left.22^{\circ} \mathrm{C}\right)$, an increase of $\left(\Phi_{\text {PSII }}\right)$ was observed.

These results suggest that during February the reduction in photochemistry found at temperatures of $11{ }^{\circ} \mathrm{C}$ and at PPFD of about $700 \mu \mathrm{mol}$ photons $\mathrm{m}^{-2} \mathrm{~s}^{-1}$ (table 1) was due to a downregulation of PSII reaction centres, rather than to an impairment of photosynthetic apparatus. This strategy may represent a safety mechanism against the photoinhibitory 
damage risk as a consequence of combined effect of low temperature and moderately high irradiances on photosystems. In this view, the lack of significant differences in maximum PSII photochemical efficiency $\left(\mathrm{F}_{\mathrm{v}} / \mathrm{F}_{\mathrm{m}}\right)$, as well as in total chlorophylls and carotenoids content between mature leaves in winter and spring supports this hypothesis, confirming that photochemical apparatus of $C$. incanus remained stable and effective at winter temperatures.

\section{Conclusions}

The results of the present study indicate that leaf age influences the photoprotection mechanisms. Under saturating irradiance and low winter temperature mature leaves of all evergreen species, by higher $\mathrm{CO}_{2}$ assimilation rates and higher thermal energy dissipation linked to the flexible component, cope more efficiently with the excess of absorbed light and result to be less sensitive to photoinhibition. On the other hand young leaves utilize the reducing power mainly in processes other than photosynthesis and show higher values of non-regulated energy dissipation in PSII. However both different mechanisms are useful in maintain the maximum PSII photochemical efficiency at comparable values in young and mature leaves.

Among species both young and mature leaves of $Q$. ilex exhibited the highest photosynthetic performance indicating a better resistance to low temperatures.

The comparison between mature leaves in winter and spring shows higher values of net photosynthesis and photochemical efficiency in all evergreen species during spring and a lower contribute of flexible and sustained thermal dissipation in winter. At low temperature, the significant increase of thermal and photochemical processes other than photosynthesis allow mature leaves of evergreen species to maintain an elevated photochemical efficiency, despite the strong reduction of carbon assimilation. Among species, $Q$. ilex showed the best photosynthetic performance under winter, indicating a better acclimation capability of photosynthetic apparatus.

In C. incanus species, during winter, young leaves showed a higher photochemical efficiency than mature leaves. The increase in photochemistry leads to a reduction of thermal dissipative processes. On the other hand, the mature leaves exhibited an opposite tendency. However, both strategies are useful in leaf photoprotection under winter since maximum PSII photochemical efficiency is high and similar in the two leaf populations.

The comparison between mature leaves in winter and spring has evidenced a lower quantum yield of PSII linear electron transport and an increase of regulated thermal dissipation processes during winter. The recovery of photochemical activity in spring under mild temperature, indicates that the drop in photochemistry in winter was due to the balance between energy absorbed and dissipated at PSII level rather than to an impairment of photosynthetic apparatus. In this context, the higher thermal dissipation in winter compensate for the reduced photochemistry, allowing maximum PSII photochemical efficiency to remain unchanged compared to spring. This may be interpreted as a dynamic regulatory process protecting the photosynthetic apparatus from severe damage by excess light at low temperature.

\section{Acknowledgments}

The authors are grateful to Prof. Mazzarella of the Department of Geophysic and Vulcanology (University Federico II Naples) for providing meteorological data and to Corpo 
Forestale dello Stato of Sabaudia (Latina, Italy) for supplying the plants used in the experiments.

\section{References}

Abril, M. \& Hanano, R. (1998). Ecophysiological responses of three evergreen woody Mediterranean species to water stress. Acta oecologica, Vol. 19, pp. 377-387, ISSN 1146-609X

Adams, W.W.; Demmig-Adams, B., Rosentiel, T.N., \& Ebbert, V. (2001). Dependence of photosynthesis and energy dissipation activity upon growth form and light environment during the winter. Photosynthesis Research, Vol. 67, pp. 51-62, ISSN (printed) 0166-8595

Arena, C.; Vitale, L. \& Virzo De Santo A. (2008). Photosynthesis and photoprotective strategies in Laurus nobilis L. and Quercus ilex L. under summer drought and winter cold. Plant Biosystems, Vol. 142, pp. 472-479, ISSN 1126-3504

Aronne, G. \& De Micco, V. (2001). Seasonal dimorphism in the Mediterranean Cistus incanus L. subsp. incanus. Annals of Botany, Vol. 87, pp. 789-794, ISSN 0305-7364

Baker, N.R. (1994). Chilling stress and photosynthesis. Causes of Photooxidative Stress and Amelioration of Defences Systems in Plants (eds C.H Foyer \& P.M. Mullineaux), pp 127-154. CRC Press, Boca Raton, Florida.

Bertamini, M. \& Nedunchezhian, N. (2003). Photoinhibition of photosynthesis in mature and young leaves of grapevine (Vitis vinifera L.). Plant Science, Vol. 164, No. 4, pp. 635644, ISSN 0168-9452

Bilger, W. \& Björkman, O. (1990). Role of the xanthophyll cycle in photoprotection elucidated by measurements of light-induced absorbance changes, fluorescence and photosynthesis in leaves of Hedera canariensis. Photosynthesis Research, Vol. 25, pp. 173-185, ISSN (printed) 0166-8595

Blondel, J. \& Aronson, J. (1999). Biology and Wildlife of the Mediterranean Region. ISBN 0 19850035 1, Oxford University Press, New York.

Boese, S.R. \& Huner, N.P.A. (1990). Effect of growth temperature and temperature shift on spinach leaf morphology and photosynthesis. Plant Physiology, Vol. 94, pp. 18301836, ISSN (printed) 0032-0889

Bussotti, F. (2008). Functional leaf traits, plant communities and acclimation processes in relation to oxidative stress in trees: a critical overview. Global Change Biology, Vol. 14, pp. 2727-2739, ISSN (printed) 1354-1013

Caemmerer, S. von \& Farquhar, G.D. (1981). Some relationship between the biochemistry of photosynthesis and the gas exchange of leaves. Planta, Vol. 153, pp. 376-387, ISSN (printed) 0032-0935

Castro-Díez, P.; Villar-Salvador, P., Pérez-Rontomé, C., Maestro-Martínez, M. \& MontserratMartí, G. (1998) Leaf morphology, leaf chemical composition and stem xylem characteristics in two Pistacia (Anarcardiaceae) species along climatic gradient. Flora, Vol. 193, pp. 195-202, ISSN 0367-2530

Choinski, Jr. \& Eamus, D. (2003) Changes in photosynthesis during leaf expansion in Corymbia gummifera. Australian Journal of Botany, Vol 51, pp. 111-118, ISSN (printed) 0067-1924

Cornelissen, J.H.C.; Lavorel, S., Garnier, E., Díaz, S., Buchmann, N., Gurvich, D.E., Reich, P.B., ter Steege, H., Morgan, H.D., van der Heijden, M.G.A., Pausas, J.G. \& Poorter 
H. (2003). Handbook of protocols for standardised and easy measurements of plant functional traits worldwide. Australian Journal of Botany, Vol. 51, pp. 335-380, ISSN (printed) 0067-1924

D'Ambrosio, N.; Arena, C. \& Virzo De Santo, A. (2006). Temperature response of photosynthesis, excitation energy dissipation and alternative electron sinks to carbon assimilation in Beta vulgaris L. Environmental and Experimental Botany, Vol. 55, pp. 248-257, ISSN 0098-8472

Demming-Adams, B.; Adams, W. W., Barker, D. H., Logan, B. A., Bowling, D. R. \& Verhoeven, A. S. (1996). Using chlorophyll fluorescence to assess the fraction of absorbed light allocated to thermal dissipation of excess excitation. Physiologia Plantarum, Vol. 98, pp. 253-264, ISSN (printed) 0031-9317

Garnier, E.; Shipley, B., Roumet, C. \& Laurent, G. (2001). A standardized protocol for the determination of specific leaf area and leaf dry matter content. Functional Ecology Vol. 15, pp. 688-695. ISSN (printed) 0269-8463

Garcìa-Plazaola, J.L.; Artetxe, U. \& Becerril, J.M. (1999). Diurnal changes in antioxidant and carotenoid composition in Mediterranean schlerophyll tree Quercus ilex (L) during winter. Plant Science, Vol. 143, pp. 125-133, ISSN 0168-9452

Garcìa-Plazaola, J.L.; Hernández, A. \& Becerril, J.M. (2000). Photoprotective responses to winter stress in evergreen Mediterranean ecosystems. Plant Biology, Vol. 2, pp. 530535, ISSN 1438-8677

Genty, B.; Briantais, J. M. \& Baker, N.R. (1989). The relationship between the quantum yield of photosynthetic electron transport and quenching of chlorophyll fluorescence. Biochimica and Biophysica Acta, Vol. 990, pp. 87-92, ISSN 0006-3002

Gratani, L. \& Ghia, E. (2002). Adaptive strategy at the leaf level of Arbutus unedo L. to cope with Mediterranean climate. Flora, Vol. 197, pp. 275-284, ISSN 0367-2530

Gratani, L. \& Varone, L. (2004). Adaptive photosynthetic strategies of the Mediterranean maquis species according to their origin. Photosynthetica, Vol. 42, No.4, pp. 551-558, ISSN (printed) 0300-3604

Huner, N.P.A.; Palta, J.P., Li, P.H. \& Carter, J.V. (1981). Anatomical changes in leaves of Puma rye in response to growth at cold-hardening temperatures. Botanical Gazette Vol. 142, pp. 55-62, ISSN 0006-8071

Hutchinson, R.S.; Groom, Q. \& Ort, D.R. (2000). Differential effects of chilling-induced photooxidation on the redox regulation of photosynthetic enzymes. Biochemistry, Vol. 39, pp. 6679-6688, ISSN (printed) 0006-2960

Jiang, C.D.; Li, P.M., Gao, H.Y., Zou, Q., Jiang, G.M. \& Li, L.H. (2005). Enhanced photiprotection at the early stage of leaf expansion in field-grown soybean plants. Plant Science, Vol. 168, pp. 911-919, ISSN (printed) 0168-9452

Kramer, D.M.; Johnson, G.; Kiirats, O. \& Edwards, G.E. (2004). New fluorescence parameters for the determination of $\mathrm{Q}_{\mathrm{A}}$ redox state and excitation energy fluxes. Photosynthesis Research, Vol. 79, pp. 209-218, ISSN (printed) 0166-8595

Klughammer, C. \& Schreiber U. (2008). Complementary PS II quantum yields calculated from simple fluorescence parameters measured by PAM fluorometry and the Saturation Pulse method. PAM Application Notes, Vol. 1, pp. 27 -35

Larcher, W. (2000). Temperature stress and survival ability of Mediterranean sclerophyllous plants. Plant Biosystems, Vol. 134, pp. 279-295, ISSN: 1126-3504 
Long, S.; Humphries, S. \& Falkowski, P.G. (1994) Photoinhibition of photosynthesis in nature. Annual Review of Plant Physiology and Plant molecular Biology, Vol. 45, pp. 633-662, ISSN 1040-2519

Mitrakos, K.A. (1980). A theory for Mediterranean plant life. Acta Oecologica, Vol. 1, pp. 245252, ISSN 1146-609X

Niyogi, K.K. (2000). Safety valves of photosynthesis. Current Opinion in Plant Biology, Vol. 3, pp. 445-460, ISSN 1369-5266

Ogaya, R. \& Peñuelas, J. (2003). Comparative seasonal gas exchange and chlorophyll fluorescence of two dominant woody species in a Holm Oak forest. Flora, Vol. 198, pp. 132-141, ISSN (printed) 0367-2530

Oliveira, G. \& Peñuelas, J. (2000). Comparative photochemical and phenomorphological responses to winter stress of an evergreen (Quercus ilex L.) and a semi-deciduous (Cistus albidus L.) Mediterranean woody species. Acta Oecologica, Vol. 21, pp. 97-107, ISSN 1146-609X

Oliveira, G. \& Peñuelas, J. (2001). Allocation of absorbed light energy into photochemical and dissipation in a semi-deciduous and an evergreen Mediterranean woody species during winter. Australian Journal of Plant Physiology, Vol. 28, pp. 471-480, ISSN 0310-7841

Oliveira, G. \& Peñuelas, J. (2002). Comparative protective strategies of Cistus albidus and Quercus ilex facing photoinhibitory winter conditions. Environmental and Experimental Botany, Vol. 47, pp. 281-289, ISSN 0098-8472

Oliveira, G. \& Peñuelas, J. (2004). Effects of winter cold stress on photosynthesis and photochemical efficiency of PSII of the Mediterranean Cistus albidus L. and Quercus ilex L. Plant Ecology, Vol. 174, pp. 179-191, ISSN (printed) 1385-0237

Ort, D.R. \& Baker, N.R. (2002). A photoprotective role for $\mathrm{O}_{2}$ as an alternative electron sink in photosynthesis? Current Opinion in Plant Biology, Vol. 5, pp. 193-198, ISSN (printed) 1369-5266

Osório, M. L., Osório, J., Vieira, A.C., Gonçalves, S. \& Romano, A. (20011). Influence of enhanced temperature on photosynthesis, photooxidative damage, and antioxidant strategies in Ceratonia siliqua L. seedlings subjected to water deficit and rewatering. Photosynthetica, Vol. 49 (1), pp. 3-12, ISSN (printed) 0300-3604

Oxborough, K. \& Baker, N.R. (1997). Resolving chlorophyll a fluorescence images of photosynthetic efficiency into photochemical and non-photochemical components calculation of $\mathrm{q}_{\mathrm{p}}$ and $\mathrm{F}_{\mathrm{v}}{ }^{\prime} / \mathrm{F}_{\mathrm{m}}{ }^{\prime}$ without measuring $\mathrm{F}_{0}{ }^{\prime}$. Photosynthesis Research, Vol. 54, pp. 135-142, ISSN (printed) 0166-8595

Poorter, H. \& Garnier, E. (1999). Ecological significance of inherent variation in relative growth rate and its components. Handbook of functional plant ecology (eds F.I. Pugnaire \& F. Valladares), pp. 81-120, New York, Marcel Dekker.

Powles, S.B. (1984). Photoinhibition of photosynthesis induced by visible light. Annual Review of Plant Physiology, Vol. 35, 15-44, ISSN 0066-4294

Rhizopoulou, S.; Angelopulos, K. \& Mitrakos, K. (1989). Seasonal variations of accumulated ions, soluble sugars and solute potential in the expressed sap from leaves of evergreen sclerophyll species. Acta Oecologica/Oecologia Plantarum, Vol. 10, pp. 311319, ISSN 1146-609X

Ryser, P. \& Urbas, P. (2000). Ecological significance of leaf life span among Central European grass species. Oikos, Vol. 91, pp. 41-50, ISSN (printed) 0030-1299 
Sage, R.F. \& Sharkey, T.D. (1987). The effect of temperature on the occurrence of $\mathrm{O}_{2}$ and $\mathrm{CO}_{2}$ insensitive photosynthesis in field grown plants. Plant Physiology, Vol. 84, pp. 658664, ISSN (printed) 0032-0889

Sánchez-Blanco, M. J.; Rodríguez, M. J., Morales, M. A., Ortuño, M. F. \& Torrecillas A. (2002). Comparative growth and water relations of Cistus albidus and Cistus monspeliensis plants during water deficit conditions and recovery. Plant Science, Vol. 162, pp. 107-113, ISSN 0168-9452

Sassenrath, G.F.; Ort, D.R. \& Portis, A.R. Jr (1990). Impaired reductive activation of stromal bisphosphatases in tomato leaves following high light. Archives of Biochemistry and Biophysics, Vol. 282, pp. 302-30, ISSN 0003-9861

Savé, R.; Castell, C. \& Terradas J. (1999). Gas exchange and water relations, In: Ecology Mediterranean Evergreen Oak Forest. Ecological Studies, F. Rodà, J. Retana, C.A. Gracia, J. Bellot (eds.), Vol. 137, pp. 135-147, Spring Verlag, Berlin \& Heidelberg, ISSN 00708356

Shirke, P.A. (2001) Leaf photosynthesis, dark respiration an fluorescence as influenced by leaf age in an evergreen tree, Prosopis Juliflora. Photosynthetica, Vol. 311, No. 7, pp. 305-311, ISSN (printed) 0300-3604

Tattini, M.; Gravano, E., Pinelli, P., Mulinacci, N. \& Romani A. (2000). Flavonoids accumulate in leaves and glandular trichomes of Phillyrea latifolia exposed to excess solar radiation. New Phytologist, Vol. 148, pp. 69-77, ISSN (printed) 0028- 646X

Teulat, B.; Monneveux, P., Wery, J., Borries, C., Sourys, I., Charrier, A. \& This, D. (1997). Relationships between relative water content and growth parameters under water stress in barley: a QTL study. New Phytologist, Vol. 137, pp. 99-107, ISSN (printed) 0028- 646X

Tjus, S.E.; Moller, B.L. \& Scheller, H.V. (1998). Photosystem I is an early target of photoinhibition in barley illuminated at chilling temperatures. Plant Physiology, Vol. 116, pp. 755-764, ISSN (printed) 0032-0889

Urban, O.; Sprtová, M., Kosvancová, M., Tomásková, I., Lichtenthaler, H.K. \& Marek, M.V. (2008). Comparison of photosynthetic induction and transient limitations during the induction phase in young and mature leaves from three poplar clones. Tree Physiology, Vol. 28, pp. 1189-1197, ISSN (printed) 0829-318X

Varone, L. \& Gratani, L. (2007). Physiological response of eight Mediterranean maquis species to low air temperatures during winter. Photosynthetica, Vol. 45, No.3, pp. 385-391, ISSN (printed) 0300-3604

Werner, C.; Correia, O. \& Beyschlag, W. (1999). Two different strategies of Mediterranean macchia plants to avoid photoinhibitory damage by excessive radiation levels during summer drought. Acta Oecologica, Vol. 20, pp. 15-23, ISSN 1146-609X

Wilson, P.J.; Thompson, K. and Hodgson, J.G. (1999). Specific leaf area and leaf dry matter content as alternative predictors of plant strategies. New Phytologist, Vol. 143, pp. 155-162, ISSN (printed) 0028- 646X 


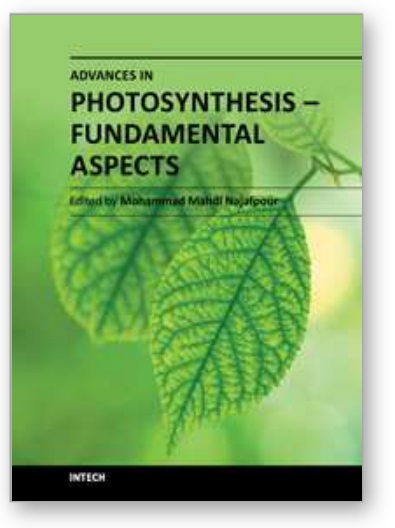

\section{Advances in Photosynthesis - Fundamental Aspects \\ Edited by Dr Mohammad Najafpour}

ISBN 978-953-307-928-8

Hard cover, 588 pages

Publisher InTech

Published online 15, February, 2012

Published in print edition February, 2012

Photosynthesis is one of the most important reactions on Earth. It is a scientific field that is the topic of many research groups. This book is aimed at providing the fundamental aspects of photosynthesis, and the results collected from different research groups. There are three sections in this book: light and photosynthesis, the path of carbon in photosynthesis, and special topics in photosynthesis. In each section important topics in the subject are discussed and (or) reviewed by experts in each book chapter.

\section{How to reference}

In order to correctly reference this scholarly work, feel free to copy and paste the following:

Carmen Arena and Luca Vitale (2012). Photosynthetic Adaptive Strategies in Evergreen and Semi-Deciduous Species of Mediterranean Maquis During Winter, Advances in Photosynthesis - Fundamental Aspects, Dr Mohammad Najafpour (Ed.), ISBN: 978-953-307-928-8, InTech, Available from:

http://www.intechopen.com/books/advances-in-photosynthesis-fundamental-aspects/photosynthetic-adaptivestrategies-in-evergreen-and-semi-deciduous-species-of-mediterranean-maquis-d

\section{INTECH}

open science | open minds

\section{InTech Europe}

University Campus STeP Ri

Slavka Krautzeka 83/A

51000 Rijeka, Croatia

Phone: +385 (51) 770447

Fax: +385 (51) 686166

www.intechopen.com

\section{InTech China}

Unit 405, Office Block, Hotel Equatorial Shanghai

No.65, Yan An Road (West), Shanghai, 200040, China

中国上海市延安西路65号上海国际贵都大饭店办公楼 405 单元

Phone: +86-21-62489820

Fax: +86-21-62489821 
(C) 2012 The Author(s). Licensee IntechOpen. This is an open access article distributed under the terms of the Creative Commons Attribution 3.0 License, which permits unrestricted use, distribution, and reproduction in any medium, provided the original work is properly cited. 